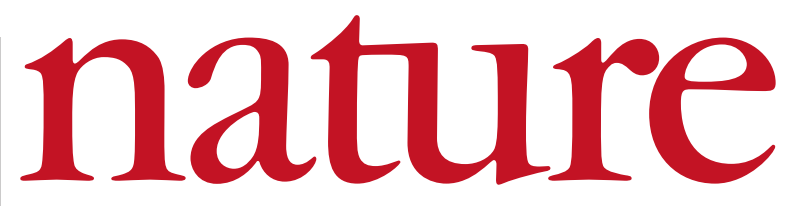

23 September 2004 Volume 431 Issue no 7007

\title{
No farewell to arms?
}

If North Korea is to bid farewell to nuclear arms, negotiators will have to convince the country that its neighbours do not themselves want to become nuclear powers. Recent activities in Japan and South Korea will make this harder.

t's easy for a totalitarian state to produce propaganda. There is no independent media, after all, to correct any lies. North Korea's nuclear weapons programme is shrouded in half-truths - mainly claims that its existence is necessary because neighbouring countries have similar ambitions. These allegations are probably false, but they would be easier to ignore if Japan and South Korea stopped fuelling North Korea's misinformation machine.

Earlier this month, for example, South Korea admitted that its scientists conducted experiments in 2000 on enriching uranium, and around two decades earlier on extracting plutonium from nuclear waste. By not reporting either project to the International Atomic Energy Agency (IAEA), the South violated the Treaty on the NonProliferation of Nuclear Weapons. The fact that this didn't come out until it was discovered by IAEA inspectors makes matters worse.

North Korea is stalling on attempts to resume talks over its weapons plans, and quickly used the revelation as proof that it needs a nuclear capability. The country is so adept at diplomatic smoke and mirrors that nuclear analysts are unsure of the size of its nuclear arsenal, or indeed if it has one at all. But it is clear that North Korea has an active nuclear programme, and the South Korean revelations have dimmed hopes that talks aimed at ending that work will resume in the coming months.

Sadly, this is not the first own-goal scored by North Korea's neighbours. In January 2003, Japan revealed that 200 kilograms of used plutonium was missing from its nuclear power complexes. Japan is also building a massive reprocessing plant for spent fuel, which could be used to produce plutonium. This, as North Korea has repeatedly pointed out, is a fuel for nuclear weapons as well as for nuclear reactors.

In truth, there is no evidence that either South Korea or Japan has a centralized weapons development programme. The hole in Japan's nuclear accounts was due to shoddy monitoring, not underhand weapons plans, the IAEA said following an inspection a month after the revelation. The agency gave the country another vote of confidence this month by halving the size of its inspection team there.

North Korea's more serious allegations about South Korea will probably also prove baseless when an IAEA team reports on the clandestine experiments next month. But the South cannot be completely innocent. Somewhere down the line, someone decided to push the research and scientists played along. Claims that the experiments were conducted in the name of basic research seem hard to believe given their obvious potential weapons applications. Many industrialized countries have the resources and expertise to conduct such experiments. Maintaining such a capability does not breach the non-proliferation treaty; doing the experiments clearly does.

On the Korean peninsula, such breaches give North Korea another reason to insist on its right to build nuclear weapons. Mismanaging nuclear resources, even civilian ones, has the same effect. That can seem a harsh lesson to have to learn when dealing with a country as manipulative and dishonest as North Korea. But if the region is to avoid a nuclear arms race, the scientists and rulers of countries that have sworn not to build nuclear weapons must stick firmly to the IAEA's rules.

\section{Time to look to the future}

Germany is understandably cautious about embryo research, but the country would benefit from joint European projects.

A fter much debate and psychological anguish, the film Der Untergang (The Downfall) was released last week in Germany. It tells the story of the last 12 days of Hitler's life, before his suicide in April 1945. In portraying Hitler as a human being rather than a one-dimensional caricature, the film breaks a 60 -year taboo, and is a measure of the evolution in Germany's attitudes to its past.

Other attitudes shaped by the Nazi period have evolved even more slowly. Last week saw the release of a report on human cloning by the influential German National Ethics Council. Its cautious tone illustrates how slow has been the evolution of attitudes towards the sanctity of life, which have been so deeply influenced by the Nazi abuse of genetics. In no other Western country is the spectrum of attitudes towards cloning so narrow, and so skewed towards conservatism.

No taboo has been broken in the report. The 25 council members, who include theologians, physicians and scientists, unanimously called for a worldwide ban on reproductive cloning. But they declined to take a vote on cloning for research purposes, going only as far as to say whether, as individuals, they supported a general ban, a temporary ban or limited approval. The German government, which established the council three years ago, was quick to jump on the general recommendation of a temporary continuation of the existing ban.

The same cautious approach was responsible for Germany's long delay in allowing any form of genetic engineering, and its late entry to the international Human Genome Project. Since then there has been pressure to catch up. It is historically understandable that Germany holds back on any work involving human embryos, but, given the increasingly clear potential of therapeutic cloning and work on human embryonic stem cells, it is important for small steps to be taken.

One such step would be for Germany to relax its rules on the use of cultured human embryonic stem-cell lines. At present, German scientists may not work on cell lines created after 2002, when the rules were fixed. However, older cell lines are of limited use in research. The European Union's Sixth Framework Programme funds research on new cultured lines, and there are German researchers who want to take part in such projects. The country will one day want to enter this field, as it did in genomics. When it does, expertise needs to be on hand. 